\title{
The relationship between the Socialist Core Values and Ideological And Political Education of College Students
}

\author{
Xiao-pu Wang ${ }^{1}$ \\ ${ }^{1}$ The Central Institute For Correctional Police \\ Baoding, China \\ Li-min Zhang ${ }^{2}$ \\ ${ }^{2}$ Humanities and Social Science of Agricultural \\ University of Hebei \\ Baoding, China
}

\author{
Qiu-ying Song ${ }^{1}$ \\ ${ }^{1}$ The Central Institute For Correctional Police \\ Baoding, China
}

\begin{abstract}
The socialist core values of the proposed has important theoretical and practical significance, especially for the ideological and political education of college students, the direction of value demands is specified,enhanced its appeal and appeal.The socialist core values enrich and innovate the ideological and political education theory and content,lead the college students' Ideological and political education in various aspects and links; the ideological and political education of college students is the important way to carry forward the socialist core values, and it must bear the socialist core values of theoretical reasoning, internalize the core values of socialism to its work, still shoulder the mission of defending the socialist core values.
\end{abstract}

Keywords: The Socialist Core Values; ideological and political education of college students; relationship

\section{INTRODUCTION}

At the Peking University teachers and students forum ,hold on May 4, 2014, Chairman Jin-ping Xi noted that "The core values carries the spiritual pursuit of a nation and a country, and embodies the value standard of a society to judge the right and wrong." ${ }^{[1]}$ The Socialist Core Values play a commanding role in the new period of the socialist modernization construction, it is the dominant values that must be pursued and followed in the construction of socialism with Chinese characteristics. The ideological and political education is the central link of the political characters of the Communist Party of China and the important way of Ideological Education.University is the important place to train the talented person for the future society, and it is the important way that developing and spreading our country's ideology and culture,still is the hope of achieving the dream of China.Therefore, the Ideological And political Education Of College Students should regard the core values of socialism as its fundamental guidelines and principles, which should run the Socialist Core Values through its education process always.

\section{The relationship between the Socialist Core Values and Ideological and Political Education}

With the continuous development of reform and opening up, China entered a new period of building a well-off society in the round,profound changes have taken place in all aspects of the life of the people's social life, which mainly embodied in the field of economy and ideology. With the rapid economic development, the diversified tendency of Ideological and culture is obvious, and the values also show a diversified situation. Our party based 
on the reality and put forward in the 17th Party Congress clearly that the construction of the ideological field in our country must persist in the core position of the socialist core value system, and then as a result to consolidate and strengthen the socialist attraction and leadership in the ideological field. The core values of socialism at the core of the core values of socialism, which concise as "Three advocacy" clearly in the eighteenth major reports of the party for the first time, is advocating rich and mighty, democracy, civilization, harmonious; liberty, egality, impartial, rule of law; patriotic, dedicated, sincerity, friendly. This is a new summary of the changes and characteristics of the ideological field in China at this stage, as the same as the fundamental principle of building a harmonious society. The ideological and political education for College Students must be engraved the brand of the socialist core values deeply, and the socialism core values should make full use of the dominated function in the entire process of the process of the education,all of these are to achieve the integration of the socialist core values and mastery of College Students' Ideological and Political Education finally.

\subsection{The Connotation of the socialist core values}

The new generalization of the core socialist values from three levels was on the Eighteenth National Congress of the CPC, rich and mighty,democracy, civilization,harmonious was advocated at the national level; liberty, egality, impartial, rule of law was advocated at the social level; patriotic,dedicated, sincerity, friendly was advocated in the personal level. This is a high summary of the spiritual connotation of the socialist core value system, and a clear answer has been given to the banner of Marxism Leninism hold high by our party in the new period and the new stage of our socialist modernization construction, persist in the construction of socialist road, towards the goal of common ideal of socialism with Chinese characteristics.It is our party's political declaration and program of action in the new period, and with vivid practice and guidance.

\subsection{The content of Ideological and Political Education}

Under the discipline system of Ideological and political education in China, ideological and political education is defined as"Ideological and political education means that certain ideas, political views, moral standards was used by social or group to exert purposeful, systematic and organized for its members, which aims at forming Social practical activity of moral character that made out by the members coincidence with the social or certain class ask for. ${ }^{\left[{ }^{[2]}\right.}$ The essence and purpose of our party's ideological and political education are realize the full development of human, which is the essence.This essence reflected in the group that the contemporary college students in China as their understanding of socialism with Chinese characteristics, The whole heart is devoted to the construction of socialism, moreover their whole heart is devoted to the construction of socialism. Thus, The current ideological and political education of college students in China must concentrate on giving full play to the advantage of social resources, helping college students recognize and fulfill their mission and responsibility, putting into the blood to achieve the great national dream and revival dream.

\subsection{The relationship between the two roles}

Building a harmonious society can not be separated from socialist core values, the construction of harmonious campus culture must also adhere to the guidance of socialist core values. Therefore, the socialist core values must throughout $\mathrm{s}$ and to guide the entire process of the students thinking and Political Education. The socialist core values want to be carried out extensively, it must be integrated with the ideological and political education of college students, and which should be examined in this process. Therefore, the relationship between the two roles is practice and theory, they influence each other, mutual fusion and none is dispensable. 


\section{The socialist core values command for the College Students' Ideological and political education}

Marxism is the scientific world outlook and methodology of the proletariat, and represents the developing and direction of the requirements of the most advanced productivity and civilization. Our party combined the deep connotation of the principle with our country's current situation formed the theory system of socialism with Chinese characteristics gradually, and summarized the core values of socialism with Chinese characteristics. And all of these are coming down in one continuous line in essence.

\subsection{Marxism is the guiding flag of the ideological and political education}

The core socialist values is the crystallization of the ideological theory that come from the combination of Marxism with socialist modernization by our party, and it fits the requirements of the modernization construction and development of our country, besides, it has a profound influence on the value orientation and value of each person. Therefore, the banner of socialist core values is the Marxism.

The persistence of the socialist core values is to hold the great banner of Marxism Leninism highly, and is to adhere to the guiding position of the Marx doctrine in ideology field, as a result, this is the spiritual pillar of the common ideal of socialism with Chinese characteristics. So the socialist core values shows the lofty value pursuit of us in the new era, reflects our party's progress in the new period in the value criterion and value judgment,realizes the organic unity of truth and value, science and faith. This has set up the basic principle for the college students' ideological and political education, besides, its theme and socialist orientation are also cleared.

\subsection{The common ideal of socialism with Chinese characteristics is the core of ideological and political education}

The essence of Ideological and political education for college students is to realize the full development of human which must be supported by ideals and beliefs. The Marxism combined the Ideal and belief with human social development's law, and then founded the historical materialism and scientific socialism, as a result it provides a theoretical premise for people to realize the ideal and belief in scientific and conscious awareness. The target of Ideological and political education for contemporary college students in China is to make the students establish the common ideal of socialist with Chinese characteristics, encourage and help them to be a useful person and be aggressive. One of the criteria for measuring the results of Ideological and political education for College Students is the results of the ideal and belief education which reflects in college students' identification about our party's ruling idea, believing in the Marxism and the common ideal of socialism with Chinese characteristics. And the socialist core values clearly expressed the common ideal of socialism with Chinese characteristics is to build a prosperous, democratic, civilized and harmonious socialist modern state, forming a social environment of freedom, equality, equality and rule of law, and cultivate patriotic, dedicated, sincere, friendly citizens in the future. This is precisely realized the closely connection of the country, society and personal development, and can mobilize the enthusiasm of the masses, form a joint force in the whole society, so this is the guarantee and prerequisite for the great Chinese dream and has very important strategic significance.

\subsection{Patriotism is the main melody of College Students' Ideological and Political Education}

The core socialist values at the personal level advocates Patriotism, dedication, honesty, friendly value demands. As the core of national spirit patriotism can cultivate the students' attachment to the country and the national, and make them self-conscious and spontaneously maintain the fine tradition of the Chinese nation and become the power source of the construction of socialist modernization.

In the core values of socialism, patriotism is the value demands of the relationship between individual and state, and it roots from personal recognition and support for the country and the nation in the emotional aspects,as a result 
the whole process is the ideological and political education in the broad sense. Meanwhile,patriotism is one of the important contents of the ideological and political education for college students, that's because the individuals always belong to a country and a nation,and the interests of individual citizens are closely related to the interest of the state and the nation, Individuals breathe with the nation together, shared destiny, and then truly maximize the interests of citizens. Love of the country and the nation is a real social practice,represents concretely in the cause that is beneficial to the country and the social development which citizens actually engaged in. And the career is the main way that every person realizes self value, and only in the dedication can truly realize self-worth.Sincerity is the moral character of the individual, patriotism and dedication are the concrete manifestation of individual inner moral character.Ancient Chinese had pointed"Sincere God", therefore, the quality of life of the individuals have a decisive role in the life of their life, and is the essence requirement to achieve the professionalism and patriotism. Friendly is a valuable appeal to the interpersonal relationship level, the inner quality of the individual is necessarily external to the friendliness of others, the realization of personal self-worth is unified on the basis of honesty and integrity. Therefore, patriotism, professionalism and kindness are the external of the intrinsic moral quality of the integrity of the moral, the four establish the perfect individual personality together.

\subsection{The socialist core values is the ideological basis and the important theoretical guarantee for the realization of the "Chinese dream"}

"China Dream"is the entity of the national dream,the revival dream and the people's dream, and i set target and banner, ideal and road in one innovative strategy.

National dream is to achieve the country's prosperity and strength, national dream is to realize the Chinese nation stands in the forest of the world, the people's dream is to keep and improve the status of the people. Jin-ping Xi pointed out, to achieve "the dream of China "'is to achieve the country's prosperity, revitalization of the people, the people's happiness." ${ }^{[3]}$ The realization of the "Chinese dream" is to benefit the people in the final analysis, in the process of the realization, the socialist core values needed to lead in the direction urgently, spiritual and driving force support. As Young college students as the main body of the society, the realization of the Chinese dream is closely linked with their fate, therefore, the university students' political beliefs and ideals are the spiritual foundation of the cause of the socialist modernization construction. At the same time, each person's value idea has the influence to the people and the individual to the periphery, and individuals are also vulnerable to social environment. The Chinese dream coincides with the time for the contemporary college students' Ideological and political education set up the dream and ideals and beliefs. Therefore, ideological and political education in universities needs the guidance of Chinese dream.

The rise of the socialist core values provides the basic principles and guidelines for the ideological and political education for college students, the "Chinese dream" has set up the ideal belief for the ideological and political education for college students, besides, the education is the realization route of the socialist core values and is the important basis for the realization of the "great Chinese dream". At the same time, the socialist core values is the mainstream values that must be respected and followed in the process of the construction of the socialist modernization and throughout the whole modernization process. Therefore, the socialist core values is the ideological basis and the important theoretical guarantee of realizing the "Chinese dream".

\section{The dissemination of he socialist core values in the Ideological and political education}

The core values of socialism is the core content and guiding principle of Ideological and political education, especially the ideological and political education of college students, at the same time, the ideological and political education of college students is the main way to develop and display the socialist core values. Therefore, 
the ideological and political education of college students also take the mission of carrying forward the socialist core values.

Firstly, the ideological and political education of college students should demonstrate the socialist core values from the aspects of ideological and theoretical and reveal its rationality and value, so as to let people be able to truly understand the value of the core values of socialism that lies, accept it indeed and eventually internalize into their own intrinsic moral qualities and moral sentiments, and then provide condition for the action of the external. So the ideological and political education of college students should integrate the core values of socialism into the real life of the students, and then turn the value into a true life belief and code of conduct. Only in this way can we make the socialist core values go to the students' ideological concept deep really, so that students can conscientiously practice the socialist core values.

Secondly, the ideological and political education of college students must integrate the core values of socialism into every part of its process. The ideological and political education of college students should take the core values of socialism as the core of its work, still more guide the entire education process in all aspects and details and realize the contents and principles of the core values of socialism's the real internalization and transmission. And then made the whole process of the ideological and political education of college students to be the way to spread and promote the socialist core values.

contemporary college students must have a thorough understanding of the spiritual connotation and the essence of the socialist core values, and have a clear and accurate judgment of the values of various values in the ideological field, in the comparison to the core values of socialism to demonstrate the superiority and the truth of the socialist core values, and then help students internalized the core values of socialism as inner moral quality, and then when face to the value of diversification of the situation, they can make right and coincidence with
Specifically speaking, firstly, the subject of the education should have a deep understanding of the spiritual connotation and the essence of the socialist core values and internalization it into their own practice activities to unity, so as to play a role in the education process; secondly, the subject of education should also have a deep understanding of the physical and mental characteristics of the special group of college students. Compared to other social groups, College students have overall quality and their cultural level are all higher, besides, they have an able to rapidly grasp the socialist core values of comprehensively and deeply. In addition, the content of the ideological and political education of college students is consistent with the socialist core values, therefore, in the ideological and political education for college students to strengthen the socialist core values of the implementation of the work is helpful to establish a scientific value orientation; Again, in the process of the ideological and political education of College Students, it is necessary to deviate the socialist core values $\mathrm{d}$ from the value of the concept of correction consciously, and bear the responsibility and mission to protect the socialist core values. Under the background of Globalization, with the globalization of economy, the diversification of culture and ideas, as a result, in the field of our country's ideology, there are many kinds of values coexist. In this case, resolutely carry forward and defend the core values of socialism has become an important mission of Ideological and political education for College Students.Therefore, the ideological and political education of

the value choice of the socialist modernization construction demand, and then in their actual life consciously practice the socialist core values;

Lastly, integrate the socialist core values into the ideological and political education of College Students, it is not only beneficial to ideological and political education in the theoretical aspects of innovation, enrich its content, and strengthen the function of ideological and political education, but also the theoretical basis for the choice of its direction and the establishment of its target. 


\section{CONCLUSION}

In a word, the relationship between the two concepts of socialist core values and ideological and political education of college students is the relationship between theory and Practice, the two roles are interdependent, indivisible and mutually promoting. The socialist core values is the value orientation, principle and principle of the ideological and political education for college students, and it provides the theoretical premise for the education, and then, the ideological and political education of college students is one of the important channels of carrying forward and carrying out the socialist core values.

The ideological and political education of college students must implement the core values of socialism in its process, and then the values can help young students firm belief in Marxism then to uphold the common ideal of socialism with Chinese characteristics, besides, help them grow to be successors of the socialist modernization drive and achieve the great dream of China to shape the main force.

\section{References}

[1]May 4,2014 Jin-ping Xi's Speech at the Faculty and Student Forum of Peking University

[2]Zhang Yaocan, Chen Wanbai. The Principle of Ideological and Political Education [M]. Higher Education Press.p.4.2001.

[3]Jin-ping Xi's Important Speech the Chinese Communist Party of the Twelfth National People's Congress a Meeting of the Closing Session 